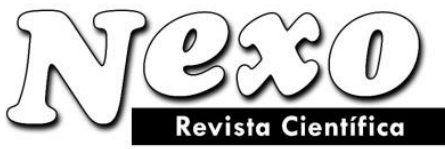

Vol. 33, No. 01, pp. 77-83/Junio 2020

\title{
GAS MICRO-TURBINES WITH HIGH-SPEED ELECTRIC GENERATORS FOR LOCAL SMART ENERGY SYSTEMS
}

\section{MICRO TURBINAS DE GAS CON GENERADORES DE ALTA VELOCIDAD PARA SISTEMAS DE ENERGIA LOCALES INTELIGENTES}

\author{
Pavel G. Kolpakhchyan, Alexander R. Shaikhiev, Elena A. Yatsenko, Boris M. Goltsman*, \\ Andrey S. Oshchepkov \\ Department of Electric Machines and Apparatus, Rostov StateTransport University, Rostov-on-Don, \\ Russia \\ *boriuspost@gmail.com
}

(recibido/received: 14-enero-2020; aceptado/accepted: 04-abril-2020)

\begin{abstract}
At present, the share of energy collected from renewable resources and low-power units is growing, and the generation becomes distributed, having many facilities that operate in co-generation mode. That is why the construction of an energy system with distributed heterogeneous sources and the improvement of its efficiency have become widely discussed issues. This paper proposes a solution of a local smart energy systemfortheTechnoEcoPark, a sciencepark of Rostov State Transport University, Rostov, Russia. The solution aims to integrate the distributed generation facilities, including environmentally friendly renewable resources, grid infrastructure and consumers with controllable and uncontrollable load. Theapproachtothe problem is the application of a smart control systemthatmanagesgeneration, distribution and consumptionof energy in a mini-CHP-based autonomous energy system. Such smart control systems reveal the trends of optimal energydistribution in a autonomousenergysystem. The study substantiates that installation of an in-house mini-CHP can solve the task of supplying heat and powertotheTechnoEcoPark. The important advantage of the solution is a significant reduction of expenses on energy consumption as the generation costs less compared to the grid tariffs. The proposed energy supply system of the TechnoEcoPark exemplifies the integration of heterogeneous heat and power sources and consumers into a commonnetwork. The paper outlines the mechanisms of the energy system efficiency improvement. These mechanisms make it possible to provide heat and power supply services to consumers and to return the generated power into the centralized grid. The materials of the paper can be of use to the specialists and researchers who are interested in generation and distribution of energy in autonomous systems.
\end{abstract}

Keywords: Autonomous energy system; Smart grid; Power generation control; Renewable energy sources; Mini-CHP; Gas microturbine

\section{RESUMEN}

En la actualidad, la proporción de energía recolectada de recursos renovables y unidades de baja potencia está creciendo, y la generación se distribuye, teniendo muchas instalaciones que operan en modo de

Nexo Revista Científica / Vol. 33, No. 01, pp. 77-83 / Junio 2020 


\section{Pavel G. Kolpakhchyan et al.}

cogeneración. Es por eso que la construcción de un sistema de energía con fuentes heterogéneas distribuidas y la mejora de su eficiencia se han convertido en temas ampliamente discutidos. Este documento propone una solución de un sistema de energía inteligente local para TechnoEcoPark, un parque científico de la Universidad Estatal de Transporte de Rostov, Rostov, Rusia. La solución tiene como objetivo integrar las instalaciones de generación distribuida, incluidos los recursos renovables ecológicos, la infraestructura de la red y los consumidores con carga controlable e incontrolable. El enfoque del problema es la aplicación de un sistema de control inteligente que gestiona la generación, distribución y consumo de energía en un sistema de energía autónomo basado en mini-CHP. Tales sistemas de control inteligente revelan las tendencias de distribución óptima de energía en un sistema energético autónomo. El estudio confirma que la instalación de un mini-CHP interno puede resolver la tarea de suministrar calor y energía al TechnoEcoPark. La ventaja importante de la solución es una reducción significativa de los gastos en consumo de energía, ya que la generación cuesta menos en comparación con las tarifas de la red. El sistema de suministro de energía propuesto por TechnoEcoPark ejemplifica la integración de fuentes heterogéneas de calor y energía y consumidores en una red común. El documento describe los mecanismos de mejora de la eficiencia del sistema energético. Estos mecanismos permiten proporcionar servicios de suministro de calor y energía a los consumidores y devolver la energía generada a la red centralizada. Los materiales del documento pueden ser de utilidad para los especialistas e investigadores interesados en la generación y distribución de energía en sistemas autónomos.

Palabras clave: Sistema de energía autónomo; Red inteligente; Control de generación de energía; Fuentes de energía renovables; Mini-CHP; Microturbina de gas

\section{INTRODUCTIÓN}

Modern power generation industry is experiencing a technological paradigm shift. Heat and power tariffs increase due to the depletion of growth potential of the centralized energy systems, the lack of competition at the retail electricity market, and inability of the inertial centralized systems to respond to the varied power demand. This results in a trending-up situation where customers abandon centralized energy systems in favour of developing distributed in-house heat and power generation. At the same time, localized power supply systems are emerging now, and the local generation facilities find themselves able to compete with the centralized generation because they are closer to consumers and, therefore, the energy transportation costs are noticeably less.

The share of energy collected from renewable resources and low-power units increases in the energy balance of many countries. Such increase leads to the fact that heat and power generation becomes distributed, having a significant number of facilities that operate in co-generation mode. In this case, efficient operation of the energy system is only possible if the operation of all system elements is coordinated; therefore, it appears reasonable to apply centralized smart process control systems in the energy sector (Ahmad, 2016; Energy USCSCo..., 2009; Liu, Chen, \& Liu, 2017; Vasiliev, Elistratov, Maslikov, \& Breusov, 2005; Wells, 2012).

\section{METHODS}

For the purposes of this study, the smart energy system (SES) of heat and power supply was developed using a science park that includes residential, industrial and academic buildings as an example.

The aim of our work was to develop a schematic solution of a local SES for TechnoEcoPark, a science park of Rostov State Transport University, Rostov, Russia, based on distributed generation facilities including environmentally friendly renewable resources, grid infrastructure and consumers with controllable and

Nexo Revista Científica / Vol. 33, No. 01, pp. 77-83 / Junio 2020 


\section{Pavel G. Kolpakhchyan et al.}

uncontrollable load. The developed system can operate both independently and in connection with the centralized energy systems. Another task of our work was to study the ways of improving the energy facilities efficiency; at that, the aim was to identify such ways that would ensure sufficient energy supply in terms of voltage and consumption, possibility to provide connection services and power transmission according to the demand, and possibility of delivering power from the in-house generation facilities to the centralized grid (Anvari-Moghaddam, Monsef, \& Rahimi-Kian, 2015; Benecke, Rueckschloss, Middendorf, Nissen, \& Lang, 2012; Oh \& Hildreth, 2016; Zhong \& Hornik, 2012).

The SES was designed to provide connection of any power suppliers and power consumers to the power grid infrastructure, thus fostering the rational use of primary heat and power sources. The priority was given to ensuring convenience of the SES to the consumers and efficient use of the energy resources.

\section{RESULTS}

The SES, based on a gas turbine complex, is proposed in modular design with the possibility to vary both heat and power production (Gabbar, 2016; Hegny et al., 2007; Huang, Jing, Zhen, \& Yi, 2016; Monti, Pesch, Ellis, \& Mancarella, 2016; Paudyal, Canizares, \& Bhattacharya, 2015).

To implement this task, a mini-CHP complex is equipped with three $2.5 \mathrm{MW}$ gas turbine (GT) units. A heat recovery steam generator (HRSG) is installed at the outlet of the heated combustion product stream and provides a $2.5 \mathrm{MW}$ steam turbine (ST) unit with steam. At the ST condenser, a heat pump is installed for heat supply. In summer, air conditioning is carried out using the same heat pump.

The schematic diagram of mini-CHP is shown in Figure 1. It includes GT units (compressor 1, combustion chamber 2, turbine 3, air duct 4, and gas duct 5) and HRSG units with the steam-water circuit (burners 6, regenerative air heater 7 , superheaters 8 , drum 9, steam-releasing surfaces 10 , water economizer 11, and network water heaters 12); the exhaust gases escape through the exhaust duct 13. Also, the diagram includes ST 14 with the regeneration system (condenser 19, condensate pumps 20, feed-water pumps 24 , ejector 21, preheater 25) and the steam condensation system in the form of a closed cycle of steam compression heat pump (HP) 18 (HP evaporator as a part of ST condenser 19 and network cooler 17; HP condensers consisting of the main condensate heater 25 and network water heater 26; throttle device 22, pump 23).

District heating system 15 and hot water system 27 with heaters 25 and 26, and cooler 17 is used in the mini-CHP for the thermal energy supply to the consumers. The power is produced by electric generators 16 which are driven by the GTs and the ST.

Due to the simultaneity of two cycles (gas turbine one and steam-power one), the combined cycle gas turbine (CCGT) unit, including an HRSG, has the power generation efficiency of about 60\% (Kolpakhchyan, Shaikhiev, \& Kochin, 2018; Kolpakhchyan, Zarifian, \& Andruschenko, 2017; Qinghua \& Fang, 2011; Yatsenko, Goltsman, Smolii, \& Kosarev, 2015).

The CCGT unit compressors inject air into the combustion chamber, where it participates in the combustion reaction with natural gas. A portion of the air is injected into the combustion chamber from the regenerative air heaters, bypassing the compressors, which enhances the efficiency of the CCGT unit in a wide range of loads. The gas temperature at the combustion chamber outlet is $900-1100^{\circ} \mathrm{C}$. Having performed its work in the GT, the gas-air mixture with a temperature of $400-500^{\circ} \mathrm{C}$ is fed into the HRSG, where it transfers the thermal energy to the heat carrier (steam-water mixture) of the steam-power cycle.

Nexo Revista Científica / Vol. 33, No. 01, pp. 77-83 / Junio 2020 


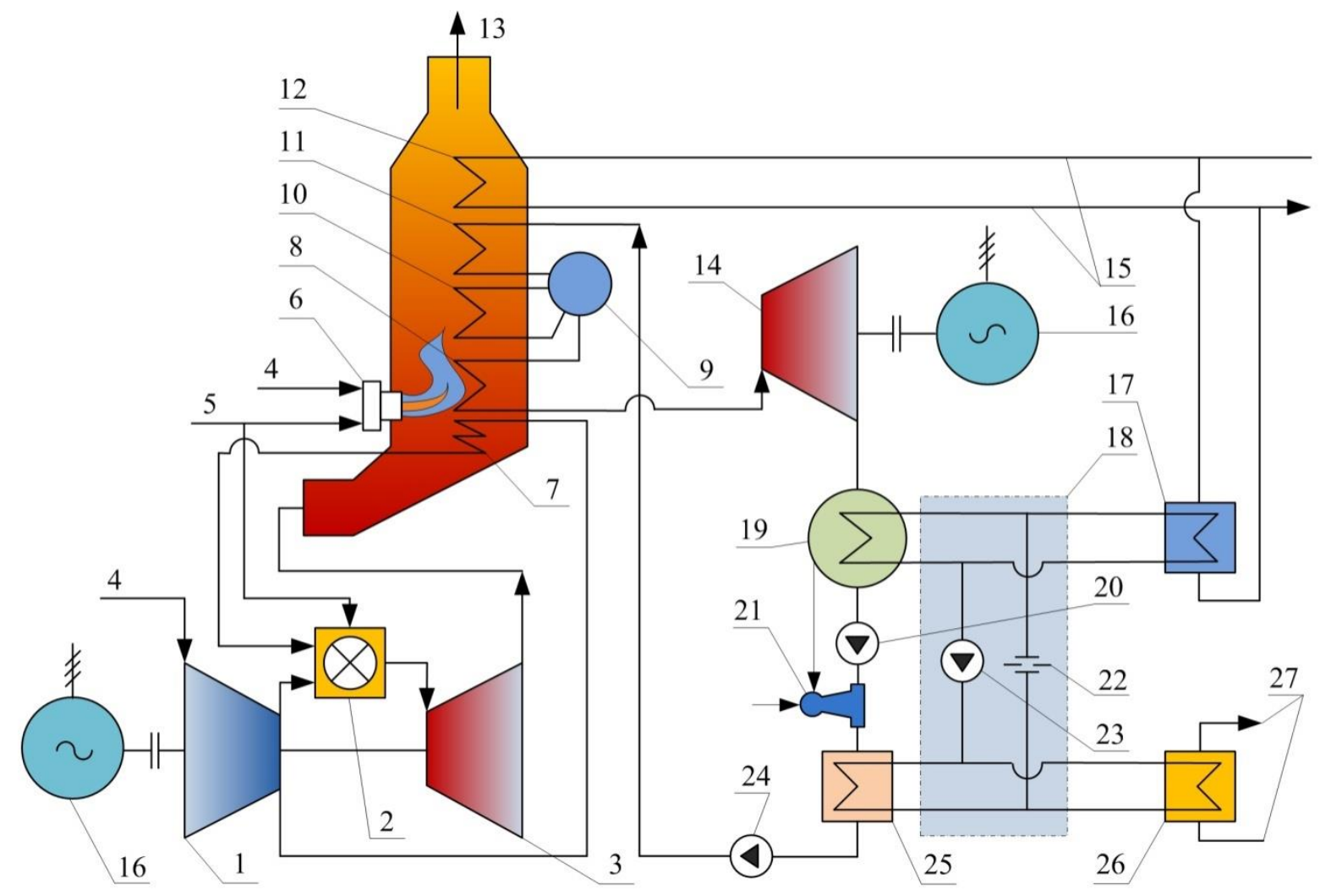

Figure 1. Schematic diagram of the mini-CHP with the total capacity of $10 \mathrm{MW}$

In the steam-power cycle, water is pressurized by the feed-water pump and fed into the HRSG. Next, water passes through the water economizer, the drum, and the steam-releasing surfaces and turns into steam. In the HRSG superheaters the steam temperature rises to $250-350^{\circ} \mathrm{C}$, and after that the steam is fed into the ST, performs the work losing its energy. The ST-exit steam parameters are $0.0035 \mathrm{MPa}$ and $25^{\circ} \mathrm{C}$. Having condensed in the condenser, the heat carrier passes through the regenerative system and enters the HRSG again.

To condense the exhaust steam after the ST, it is proposed to use a complex of 4-6 vapor-compression heat pumps with a thermal unit capacity up to 2,400 kW and a cooling capacity from $1600 \mathrm{~kW}$.

Thermal power of the mini-CHP reaches $20 \mathrm{MW}$, which is sufficient for the heating of network water for high-temperature water supply.

The heating networks of the TechnoEcoPark can operate for heating the building in winter and air conditioning in summer, which enhances the efficiency of the heating networks and saves pipe laying costs. In winter, the heating networks transfer hot water from the mini-CHP to the buildings, and in summer, the same networks can transfer a coolant to the conditioning system of the buildings (using fancoil-type systems).

The mini-CHP can operated independently, without connection to the external power grid. In this case, the mini-CHP compensates the irregular power consumption during the day only by changing the load of its own units (Abeuov, Baranovskiy, \& Khrushchev, 2005; Layadi, Champenois, \& Mostefai, 2015; Zhaoyu, Bokan, Jianhui, Begovic, \& Chen, 2015). Given the variable power consumption, the fluctuations of electrical load can reach $70 \%$, hence some of the units should be able to shut down. The mini-CHP design incorporates such a possibility to start and shut down separate units. 


\section{Pavel G. Kolpakhchyan et al.}

However, the mini-CHP can operated when connected to the external power grid, subject to the approvals from electricity suppliers. In this case, the unused electricity can be sold to external customers, and the load fluctuations can be regulated by external system operators, hence the load fluctuations are less.

The reduction of both heat and power load is carried out by changing the GT and ST operation modes. Upon reducing the GT and ST load, the heat pump continues to operate at full capacity thus enhancing the efficiency of the mini-CHP.

Each local power supply system is connected to the common local system and provides the remote control of the basic operational parameters and the monitoring of energy generation and consumption data through a single control centre. It is possible to organize monitoring systems via the Internet.

\section{DISCUSSIONS}

The local SES, based GT units with high-speed generators, was designed to provide sustainable and reliable power supply to consumers of the science park of Rostov State Transport University and efficiently operate in connection with various distributed generation facilities (centralized power grid, own generation facilities, power plants based on renewable energy sources, and others) through the grid infrastructure, including energy storage units (Bollen, 2011; Yazdanian \& Mehrizi-Sani, 2014). This

energy system operates on tri-generation mode and supplies electricity and heating to the consumers and cooling for air conditioning, ventilating and making arena ice.

It is proposed to include the following sources in to the local energy system, connected to the centralized grid:

- in-house mini-CHP (the main energy source) based on GT units with high-speed power generators and operating in tri-generation mode;

- transformer substations and switchgear;

- photovoltaic power plant (including a central module and smaller modules distributed over the TechnoEcoPark and integrated into a single system);

- wind power plant (consisting of 3 units combined in a single plant);

- heat pump plants (high-capacity heat pumps (HP) as a part of the mini-CHP and heat pump plants (HPP) distributed over the TechnoEcoPark);

- solar heliostations (distributed over the science park and combined in a single heating, cooling and hot water supply system);

- heat and power accumulation systems (storages of electric and thermal energy as part of the mini-CHP and HPP distributed over the TechnoEcoPark);

- automated monitoring and metering systems that control production and consumption of power and heat, with the function of managing payments from the energy consumers;

- automatic control, fault detection and power equipment protection system;

- SES control and communication centre.

Taken together, these SES elements solve the problem of supplying the science park with various types of energy. The benefits of the proposed solution are significant reduction of the energy expenses as the inhouse generation costs are less than the grid tariffs. Moreover, the in-house CHP gives energy selfsufficiency and sustainability of operational processes in case of possible outages in the centralized grid. It should also be noted that under the condition of energy deficit, an in-house CHP can be the only way to maintain the required consumption (Bush, 2014; Gellings, 2009; Momoh, 2012).

\section{CONCLUSIONS}

Nexo Revista Científica / Vol. 33, No. 01, pp. 77-83 / Junio 2020 


\section{Pavel G. Kolpakhchyan et al.}

To summarize, the proposed CHP solution puts into practice the optimal modes of generation, control, transformation and distribution of energy from primary thermal and electrical sources, including renewable and non- renewable ones. A shift to such smart energy systems can significantly boost the development of distributed energy complexes while increasing their stability, flexibility, efficiency and convenience for the consumers.

\section{RECOMMENDATIONS}

The materials of this paper can be of use to the specialists and researchers who are interested in generation and distribution of energy in autonomous systems. The proposed energy system of the TechnoEcoPark can serve as an example of integration of diverse energy sources and consumers into a common network. The system efficiency is ensured by the use of intelligent control. Also, not without interest is the example of a mini-CHP operated as the main energy source and its integration with the other distributed sources using alternative types of energy.

\section{ACKNOWLEDGEMENTS}

This study was performed under the Agreement No. 14.604.21.0174 dd. 26 September 2017; the research topic 'Development of scientific and technical solutions of an efficient high-speed generator equipment for micro-GTUs' was assigned by the Ministry of Education and Science of Russia within the framework of the Federal Targeted Program 'Priority development areas in Russia's scientific and technological complex for 2014-2020’. Applied research (project) identifier is RFMEFI60417X0174.

\section{REFERENCES}

Abeuov, B., Baranovskiy, I. D., \& Khrushchev, J. V. (2005). Operation conditions of gas-turbine plants in electrical power system. Power Tech, 2005 IEEE Russia, 1-2, 27-30.

Ahmad, A. (2016). Smart Grid as a Solution for Renewable and Efficient Energy. IGI Global.

Anvari-Moghaddam, A., Monsef, H., \& Rahimi-Kian, A. (2015). Optimal Smart Home Energy Management Considering Energy Saving and a Comfortable Lifestyle. Smart Grid, IEEE Transactions, 6(1), 324-332.

Benecke, S., Rueckschloss, J., Middendorf, A., Nissen, N. F., \& Lang, K. (2012). Environmentally conscious design of autonomous power supplies for distributed micro-systems. Sustainable Systems and Technology (ISSST), 2012 IEEE International Symposium, 1-5, 16-18.

Bollen, M. H. J. (2011). The Smart Grid: Adapting the Power System to New Challenges. Morgan \& Claypool.

Bush, S. F. (2014). Smart Grid: Communication-Enabled Intelligence for the Electric Power Grid. Wiley.

Energy USCSCo, Resources N. Smart grid initiatives and technologies: hearing before the Committee on Energy. 2009. U.S. G.P.O.

Gabbar, H. (2016). Smart Energy Grid Engineering. Elsevier Science.

Gellings, C. W. (2009). The Smart Grid: Enabling Energy Efficiency and Demand Response. Fairmont Press.

Hegny, I., Holzer, R., Grabmair, G., Zoitl, A., Auinger, F., \& Wahlmuller, E. (2007). A Distributed Energy Management Approach for Autonomous Power Supply Systems. Industrial Informatics, 2007 th IEEE International Conference, 2(23-27), 1065-1070.

Huang, Q., Jing, S., Zhen, W., \& Yi, J. (2016). Innovative Testing and Measurement Solutions for Smart Grid. Wiley. 


\section{Pavel G. Kolpakhchyan et al.}

Kolpakhchyan, P. G., Shaikhiev, A. R., \& Kochin, A. E. (2018). Sensorless Control of the High-Speed SwitchedReluctance Generator for the Steam Turbine. In: A. Abraham, S. Kovalev, V. Tarassov, V. Snasel, M. Vasileva, \& A. Sukhanov (eds). Proceedings of the Second International Scientific Conference "Intelligent Information Technologies for Industry” (IITI'17). Advances in Intelligent Systems and Computing, 680.

Kolpakhchyan, P., Zarifian, A., \& Andruschenko, A. (2017). Systems Approach to the Analysis of Electromechanical Processes in the Asynchronous Traction Drive of an Electric Locomotive. In: A. Sładkowski (ed.). Rail Transport-Systems Approach. Studies in Systems, Decision and Control 87. Cham: Springer. pp. 67-134. ISBN 978-3-319-51502-1.

Layadi, T. M., Champenois, G., \& Mostefai, M. (2015). Modeling and Design Optimization of an Autonomous Multisource System under a Permanent Power-Supply Constraint. Sustainable Energy, IEEE Transactions, 6(3), 872-880.

Liu, J., Chen, S., \& Liu, T. (2017). Smart Energy: From Fire Making to the Post-Carbon World. CRC Press.

Momoh, J. (2012). Smart Grid: Fundamentals of Design and Analysis. Wiley.

Monti, A., Pesch, D., Ellis, K., \& Mancarella, P. (2016). Energy Positive Neighborhoods and Smart Energy Districts: Methods, Tools, and Experiences from the Field. Elsevier Science.

Oh, S. C., \& Hildreth, A. J. (2016). Analytics for Smart Energy Management: Tools and Applications for Sustainable Manufacturing. Springer International Publishing.

Paudyal, S., Canizares, C.A., \& Bhattacharya, K. (2015). Optimal Operation of Industrial Energy Hubs in Smart Grids. Smart Grid, IEEE Transactions, 6(2), 684-694.

Qinghua, W., \& Fang, F. (2011). Optimal configuration of CCHP system based on energy, economical, and environmental considerations. Intelligent Control and Information Processing (ICICIP), 2011 2nd International Conference, 1(25-28), 489-494.

Vasiliev, J. S., Elistratov, V. V., Maslikov, V. I., \& Breusov, V. P. (2005). An autonomous power supply of consumers on the base of combined use of renewable resources. Power Tech, 2005 IEEE Russia, 1-2, 27-30.

Wells, Q. (2012). Smart Grid Home. Cengage Learning.

Yatsenko, E. A., Goltsman, B. M., Smolii, V. A., \& Kosarev, A. S. (2015). Foamed slag glass - eco-friendly insulating material based on slag waste. Environment and Electrical Engineering, 2015 IEEE 15th International Conference, pp. 819-823.

Yazdanian, M., \& Mehrizi-Sani, A. (2014). Distributed Control Techniques in Microgrids. Smart Grid, IEEE Transactions, 5(6), 2901-2909.

Zhaoyu, W., Bokan, Ch., Jianhui, W., Begovic, M. M., \& Chen, Ch. (2015). Coordinated Energy Management of Networked Microgrids in Distribution Systems. Smart Grid, IEEE Transactions, 6(1), 45-53.

Zhong, Q. C., \& Hornik, T. (2012). Control of Power Inverters in Renewable Energy and Smart Grid Integration. Wiley. 